\title{
Influence of the North Atlantic Subtropical High on wet and dry sea-breeze events in North Carolina, United States
}

\author{
Influencia del Anticiclón del Atlántico Norte en la pluviosidad \\ de la brisa marina en Carolina del Norte, Estados Unidos
}

\author{
Nicholas T. Luchetti ${ }^{1}$ \\ Rosana Nieto Ferreira ${ }^{2}$ (iD \\ Thomas M. Rickenbach ${ }^{3}$ \\ Mark R. Nissenbaum ${ }^{4}$ \\ Joel D. McAuliffe ${ }^{5}$
}

\begin{abstract}
The sea-breeze (SB) is an important source of summertime precipitation in North Carolina (NC, southeast United States). However, not all SB events produce precipitation. A climatology of wet and dry $\mathrm{SB}$ events in NC is used to investigate the conditions that are conducive to precipitation associated with the sea breeze.

Radar imagery was used to detect 88 SB events that occurred along the NC coast between MaySeptember of 2009-2012. The majority (85\%) of SB events occurred during offshore flow (53\%) or during flow that was parallel to the coast (22\%). SB events were separated into dry (53\%) and wet (47\%) events and differences in the dynamic and thermodynamic parameters of the environment in which they formed were analyzed. Significant differences in dynamic and thermodynamic conditions were found. SB dry events occurred under stronger winds $\left(6.00 \pm 2.36 \mathrm{~ms}^{-1}\right)$ than SB wet events $\left(4.02 \pm 2.16 \mathrm{~ms}^{-1}\right)$. Moreover, during SB wet events larger values of convective available potential energy and lower values of convective inhibition were present, conditions that favor precipitation. Overall, the SB wet events accounted for $20-30 \%$ of the May-September precipitation along the NC coastal region. The position of the North Atlantic Subtropical High (NASH) controls both moisture availability and winds along the NC coast, thus providing a synoptic-scale control mechanism for SB precipitation. In particular, it was shown that when the NASH western ridge is located along the southeast coast of the United States, it causes a moist southwesterly flow along the NC coast that may favor the occurrence of SB wet events.
\end{abstract}

Keywords: Sea breeze; precipitation; North Carolina; North Atlantic Subtropical High; wind direction; wind speed.

\footnotetext{
1 Department of Geography, Environment and Planning. East Carolina University. Greenville, NC 27858-4353 USA. luchettin14@students.ecu.edu 2 Department of Geography, Environment and Planning. East Carolina University. Greenville, NC 27858-4353 USA. ferreirar@ecu.edu

3 Department of Geography, Environment and Planning. East Carolina University. Greenville, NC 27858-4353 USA. rickenbacht@ecu.edu

4 Department of Earth, Ocean and Atmospheric Science. Florida State University. Tallahassee, FL 32306-4520 USA. mrn16b@my.fsu.edu

5 School of Meteorology, University of Oklahoma, Norman, OK 73072, USA.joel.mcauliffe@ou.edu
} 


\section{Resumen}

La brisa marina (BM) es una importante fuente de precipitación de verano en Carolina del Norte (NC en su sigla en inglés), sudeste de Estados Unidos. Sin embargo, no todos los eventos de BM producen precipitación. En este trabajo se utiliza una climatología de eventos de BM lluviosos y secos en NC para investigar las condiciones que conducen a la precipitación.

Se utilizaron imágenes de radar para detectar 88 eventos de BM ocurridos a lo largo de la costa NC entre mayo y septiembre de 2009 a 2012. La mayoría (85\%) de los eventos de BM ocurrieron durante períodos de viento hacia el mar (53\%) o viento paralelo a la costa (22\%). Los eventos BM se separaron en eventos secos (53\%) y lluviosos (47\%) y se analizaron las diferencias en los parámetros dinámicos y termodinámicos del entorno en el que se formaron. Se encontraron diferencias significativas en las condiciones dinámicas y termodinámicas. Eventos de BM secos ocurrieron bajo vientos más fuertes $(6,00 \pm 2,36 \mathrm{~ms}-1)$ que los eventos de BM lluviosos $(4,02 \pm 2,16 \mathrm{~ms}-1)$. Las BM lluviosas ocurrieron bajo valores de energía potencial convectiva disponible más altos y valores del parámetro de inhibición convectiva más bajos, condiciones que favorecen la lluvia. En general, los eventos de BM lluviosos representaron el 20-30\% de la precipitación a lo largo de la región costera de NC de mayo a septiembre. La posición de la Alta Subtropical del Atlántico Norte (ASAN) controla la disponibilidad de humedad y los vientos a lo largo de la costa de NC, proporcionando así un mecanismo de control de escala sinóptica para la precipitación de la BM. En particular, cuando la cresta occidental de la ASAN se localiza a lo largo de la costa sureste de los Estados Unidos, se produce un flujo de sudoeste húmedo a lo largo de la costa NC que puede favorecer la ocurrencia de eventos de BM lluviosos.

Palabras clave: Brisa marina; lluvia; Carolina del Norte; alta Subtropical del Atlántico Norte; vientos de escala sinóptica.

\section{Introduction}

Located in the subtropics along the east coast of the United States (figure 1), North Carolina (NC, southeast United States) has a humid subtropical climate with mild winters and hot summers (e.g., Gil Olcina and Olcina Cantos, 2017). The state is flanked by the Blue Ridge Mountains to the west and by the warm waters of the Gulf Stream to the east and is naturally divided into three major geographic regions: Mountains, Piedmont and Coastal Plains (figure 1). This geography creates significant east-west differences in the annual precipitation regimes of the mountainous west, central Piedmont and Coastal Plains (figure 2). The largest annual precipitation amounts fall in the Mountains (up to $2500 \mathrm{~mm}$ per year in some locations) and Coastal Plains (over $1400 \mathrm{~mm}$ per year), with a relative minimum in the Piedmont region. During the winter, mid-latitude cyclones (e.g., Curtis, 2006; Nieto-Ferreira, Hall and Rickenbach, 2013; 2015) bring abundant precipitation, particularly to the mountainous west. Snow amounts vary from $25 \mathrm{~mm}$ (liquid equivalent) per year at the coast, to $250 \mathrm{~mm}$ in the Piedmont and $400 \mathrm{~mm}$ in the Mountains region with some high mountain peaks accumulating over $1200 \mathrm{~mm}$ of snowfall (State Climate Office of North Carolina. SCONC a,b, 2017). During summertime the main rainmakers in NC are local afternoon thunderstorms (Winkler, Skeeter and Yamamoto, 1988), sea breeze circulations (Koch and Ray, 1997), orographically-enhanced storms (Parker and Ahijevich, 2007), the occasional frontal passage (Nieto Ferreira et al., 2013; 2015) and thermal circulations associated with varying soil types along the Carolina Sandhills (Boyles, 2006; Sims and Raman, 2016). Its geographic location, protruding into the warm waters of the Gulf Stream and into the track of Atlantic tropical cyclones, makes North Carolina the state with the second highest number of tropical cyclone strikes in the country, right behind Florida (e.g., Larson, Zhou and Higgins, 2005; Shepherd, Grundstein and Mote, 2007).

The summertime precipitation along the NC coast is heavily dependent on convection induced by the sea breeze (SB). The SB has been shown to be influenced by the shape of the coastline (Gilliam et al., 2004; Steele et al., 2014), interactions with topography (Zhu and Atkinson, 2004; Azorin-Molina, Tijm, Ebert, Vicente-Serrano and Estrela, 2015; Naor, Potcher, Shafir and Alpert, 2017) and interactions with ocean currents such as the Gulf Stream (Jacobs, Lackman and Raman, 2005). Previous studies of SB fronts in NC have focused on numerical and observational case studies of the effects of geophysical variables on SB evolution (Ray, 1995; Koch and Ray, 1997; Gilliam et al., 2004). However, the effect of larger-scale dynamic and thermodynamic meteorological conditions on SB front precipitation initiation in coastal NC is not well understood. In particular, the role of large-scale atmospheric circulations such as the North Atlantic Subtropical High (NASH) on SB precipitation has not been studied. The research pre- 
sented herein aims to fill this gap by using radar and reanalysis datasets from May-September 2009-2012 to construct a climatology of precipitating, or 'wet' and non-precipitating, or 'dry' SB events that focuses on local and remote controls on the NC coast.

The dominant summertime climatological feature affecting the southeast United States (SE US) is the NASH, a summertime large-scale semi-permanent anticyclone over the North Atlantic. The NASH strongly influences winds and precipitation in the SE US. The western edge of the NASH (also known as the NASH western ridge) is characterized by southerly winds and a northward flux of warm humid air. Moisture transport and vertical velocity fluctuations along the NASH western ridge have been shown to strongly affect summertime precipitation variability in the southeast United States (e.g., Diem, 2006; Carlson, 2009; Li, Li and Kushnir, 2012). For instance, when the NASH western ridge is located southwest of its climatological mean, the southeast United States experiences wetter summers. On the other hand, when the NASH western ridge is located northwest of its climatological mean, the southeast United States experiences drought conditions (Li et al., 2012). The role of the NASH on the evolution of the SB in the SE U.S. and North Carolina in particular, remains to be investigated.

Figure 1. The study region spans the NC coastline and includes the Raleigh (KRAX), Wilmington (KLTX) and Morehead City radar sites (KMHX), with $200 \mathrm{~km}$ radar range indicated. The outlines of the Mountains, Piedmont and Coastal Plains regions are shown in grey

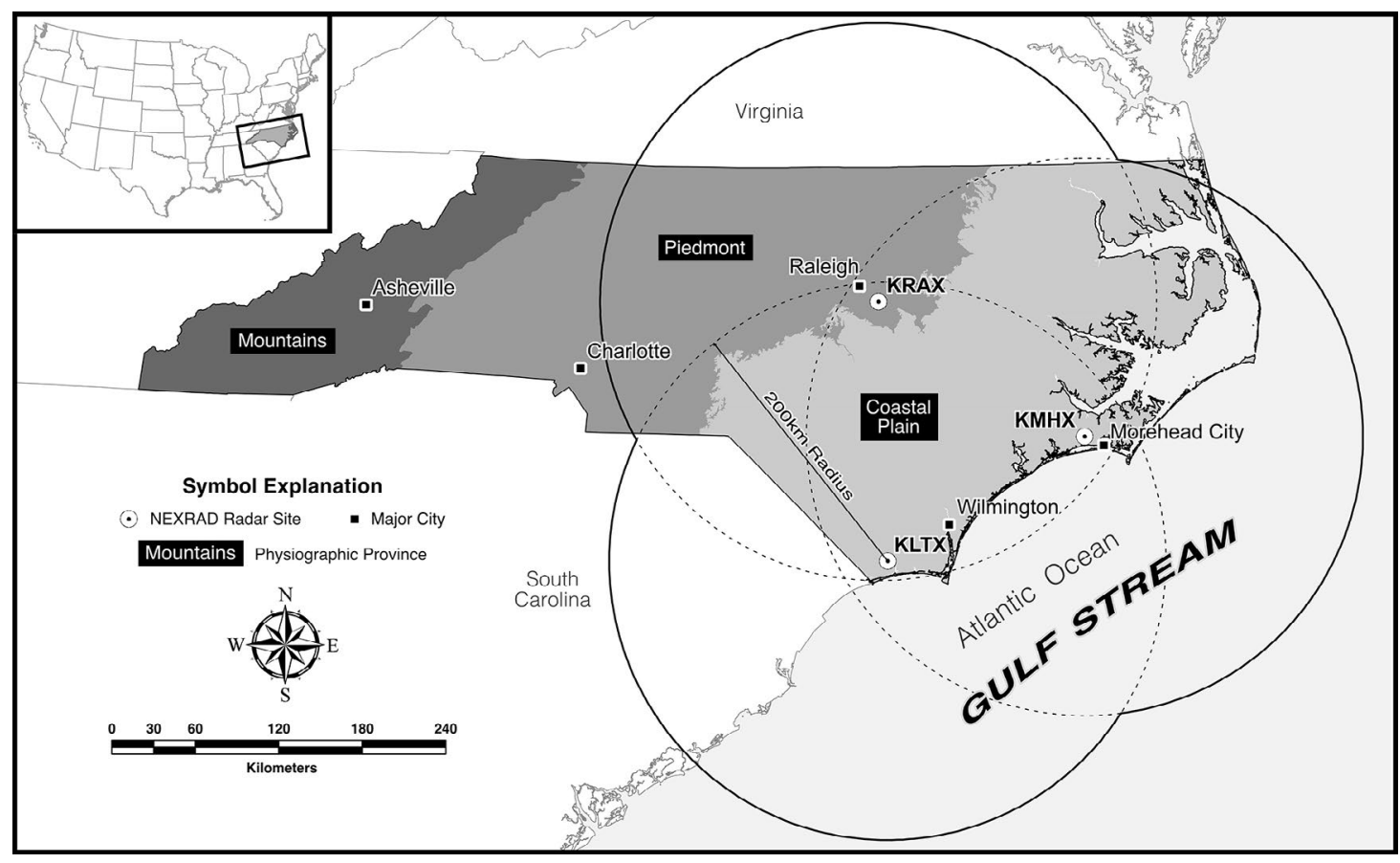

Elaboration by R. Howard, East Carolina University Center for Geographic Information Science.

Sea breezes along the NC coast occur preferably in the northeast-southeast facing coastline between Morehead City and the state border with South Carolina (Boyles, 2006) and propagate 50-150 km inland (Koch and Ray, 1997; Gilliam, Raman and Niyogi, 2004). Using radar and surface wind data, Koch and Ray (1997) found that SBs develop along the NC coast on 88\% of the days between May and September. Boyles (2006) used surface precipitation data to study the sea breeze along the coast of North Carolina, South Carolina and Georgia and found that SB precipitation was present on one third of the days between April and August. Boyles (2006) found that the sea breeze accounted for about one third of the April-August precipitation within the inland region $150 \mathrm{~km}$ from the NC coast. Given its substantial contribution to total precipitation the SB is of great importance for eastern NC. It affects agriculture, recreational activities and local tourism (e.g., Gilliam et al., 2004), coastal wind energy (Shaw, Lundquist and Schreck, 2009; Steele, Dorling, Glasow and Bacon, 2014), pollutant transport and air quality (e.g., Lyons and Olsson, 1973), as well as moderating temperatures during heat waves (e.g., Fuhrmann, Konrad, Kovach and Perkins, 2011). Despite its importance, forecasting the SB and particularly whether it will produce precipitation, remains a difficult task for coastal meteorologists. 


\section{Normal Precipitation}

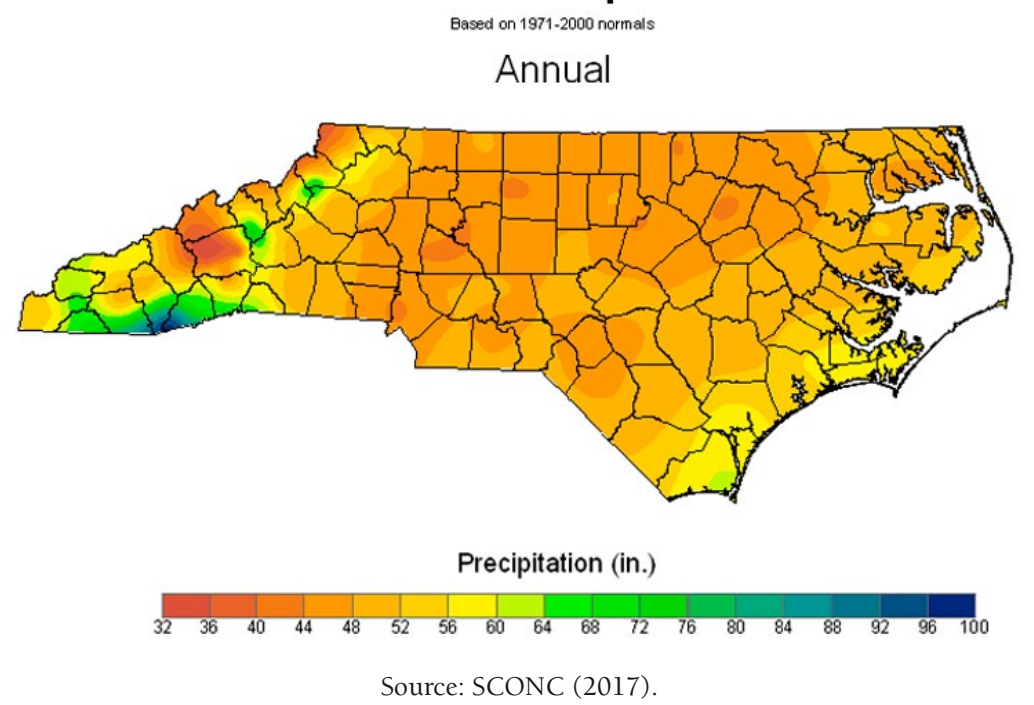

On the landward branch of the SB circulation, an SB front can develop. The SB front marks the boundary between warmer land air and cooler ocean air. Boundary layer convergence along the sea breeze front causes sharp gradients of temperature, moisture and wind that can often be seen as a 'thin line' reflectivity signature on radar. The thin line is a region of enhanced radar reflectivity seen in the clear boundary layer (Atkins and Wakimoto, 1997) that is associated with boundary layer convergence and uplift along the sea breeze front or the gust front of thunderstorms (Wilson, Weckwerth, Vivekanandan, Wakimoto and Russell, 1994). While some debate over what causes these clear-air echoes still remains, it is widely accepted that the thin line is due to the presence of insects that are transported into the convergence zone and updraft (Wilson et al., 1994) or due to Bragg scattering from differences in refractive index along the air mass gradient separated by the SB (Atlas, 1960; Atkins and Wakimoto, 1997). Regardless of the presence of precipitation, the presence of an SB thin-line near/along the coast is a telltale sign of the presence of the sea breeze.

Crosman and Horel (2010), present an extensive review of the vast body of numerical modeling studies that address the effects of ten geophysical variables on SB evolution. They found that the primary drivers of SB evolution are the differential heating between land and water, land-surface sensible heat flux and the direction and speed of the synoptic-scale wind flow in relation to the shoreline. In particular, the direction and strength of the synoptic-scale wind are the most influential factors because they affect SB development, propagation, intensity, arrival time and termination (Arritt, 1993; Atkins and Wakimoto, 1997; Azorin-Molina and Chen, 2009; Gilliam et al., 2004).

It is important to distinguish between the local flow of the SB and the synoptic scale flow within which the SB is embedded. Although the SB itself tends to propagate onshore, the synoptic-scale flow in which it is embedded can be either shore-perpendicular (onshore/offshore) or shore-parallel. This synoptic-scale flow classification is commonly used in the literature and is adopted here (e.g. Atkins and Wakimoto, 1997). Previous studies (Estoque, 1962; Bechtold, Pinty and Mascart, 1991; Arritt, 1993; Kingsmill, 1995; Atkins and Wakimoto, 1997; Gilliam et al., 2004) show that the synoptic-scale flow affects the evolution of the SB and the intensity of associated precipitation. Onshore synoptic-scale flow favors weaker sea breezes that form later in the day and propagate long distances inland. Offshore synoptic scale flow favors stronger sea breezes that form earlier in the day and propagate only short distances inland. Coast-parallel synoptic-scale flow creates sea breezes whose evolution is intermediate to that of onshore and offshore flow cases (e.g., Zhong and Tackle, 1993; Adams, 1997; Gilliam et al., 2004).

Previous studies have found that when the synoptic-scale flow is offshore it acts to sharpen the horizontal temperature gradient along the SB front, aiding frontogenesis (Miller, Keim, Talbot and Mao, 2003). Arritt (1993) used a two-dimensional primitive equation model to study SB formation under coast-perpendicular flows of varying intensities. He found that the maximum SB intensity (measured by horizontal winds and vertical velocities) occurs under offshore synoptic-scale wind speeds of 0 to $6 \mathrm{~ms}^{-1}$ 
and that the SB was weak or absent for offshore synoptic scale winds stronger than $11 \mathrm{~ms}^{-1}$. The inland propagation of the SB front decreases as offshore synoptic winds increase (Crosman and Horel, 2010). The strongest vertical velocities and horizontal winds along the SB are associated with offshore winds that can maximize frontogenesis and stall the inland penetration of the SB front (Savijarvi and Alestalo, 1988; Bechtold et al., 1991; Arritt, 1993).

Onshore synoptic scale flow on the other hand, tends to weaken the horizontal temperature gradient (Miller et al., 2003). As a result, cooler ocean air can spill inland behind the SB front much sooner in the event, weakening the SB front and circulation. Onshore synoptic scale wind stronger than $2-4 \mathrm{~m} / \mathrm{s}$ is sufficient to fully suppress the sea-breeze circulation (Aritt, 1993). Yet Gilliam et al., (2004) found that during light onshore flow along the NC coast, the SB front can move inland significant distances but may not be detectable until late in the afternoon. Gilliam et al., (2004) explored SB evolution in the varying synoptic wind directions on the NC coast. They found that the strength and inland propagation of SB fronts varies along the NC coast due to the curvature of the coastline.

When the synoptic-scale flow is parallel to the coast the SB is not detectable until later in the afternoon when convergence along the SB front is stronger (Atkins and Wakimoto, 1997). Gillian et al., (2004) shows that the SB can propagate farther inland during parallel synoptic scale flow than during onshore flows. Synoptic-scale parallel flow SBs can be divided into two types, corkscrew and backdoor SBs (e.g., Adams, 1997; Miller et al., 2003; Steele et al., 2014). During a corkscrew SB in the northern hemisphere the flow is parallel to the coast with the land to the left of the flow. In the northern hemisphere this means that there is higher pressure over the ocean and the flow develops an onshore component that allows the SB to form early in the day and become strong. Conversely, when the flow is parallel to the coast with the land to the right, a backdoor SB occurs. In a backdoor SB there is low pressure over the ocean and the flow develops an offshore component that results in a weaker SB that forms farther offshore, arrives on land later in the day and may take the form of pulses rather than a strong, steady SB (Adams, 1997).

The discussion above demonstrates the central role played by the synoptic scale flow direction and intensity on SB evolution. This study uses radar, satellite and reanalysis datasets from 2009-2012 to study local and remote controls on SB precipitation along the NC coast. Specifically this study examines SB precipitation in the context of wind and thermodynamic conditions associated with offshore, parallel and onshore synoptic flow, as controlled by the NASH circulation.

The study area is the section of North Carolina coastline that stretches from Morehead City, NC to the South Carolina border (figure 1). This portion of the coastline experiences a high frequency of SBs that are visible as a thin line reflectivity signature on radar, such as the one seen in figure 3. North Carolina's unique curved coastline features a series of three prominent capes (figure 1). The curved nature of the coastline between these capes often allows distinct SB fronts to develop, from westward propagating SB on east facing beaches to northward propagating SB on south facing beaches.

This study is organized as follows. Section 2 discusses the datasets and methodology used in this study including the area of interest and criteria for the detection and classification of the SB. Section 3 discusses classification of SB events and main synoptic scale dynamic and thermodynamic conditions for their formation. Discussion of results is presented in Section 4 and Conclusions are presented in Section 5.

\section{Datasets and Methodology}

This study uses radar, satellite, sounding and reanalysis data from May-September 2009-2012 to detect $\mathrm{SB}$ events along the $\mathrm{NC}$ coast and investigate the local and remote factors that lead to the occurrence of precipitation along the $\mathrm{SB}$.

\subsection{Datasets}

The various datasets used in this study are listed in Table 1. Unprocessed, native format NEXRAD (Next-Generation Radar) Level II radar data for the Morehead City (KMHX) and Wilmington (KLTX) radar sites (figure 1) was used to detect SB events during the study period. This data is available through the National Oceanic and Atmospheric Administration (NOAA) National Centers for Environmental Information (NCEI) NEXRAD Inventory database (NCEI, 2015). The NEXRAD Level II data contains reflectivity, mean radial velocity and spectrum width and is available at temporal resolutions of 4-10 min (depending on the radar scan pattern) with a $300 \mathrm{~m}$ sampling length along each scan azimuth. The lowest radar tilt angle available ( $\sim 0.5$ degrees) is used in this study to best capture a low-level feature such as the SB. 
Table 1. Summary of datasets used in this study

\begin{tabular}{|c|c|c|c|c|c|}
\hline Dataset & Domain & Resolution & Time & Variables & Application \\
\hline $\begin{array}{c}\text { NEXRAD radars } \\
\text { (NCEI, 2015) }\end{array}$ & $\begin{array}{c}\text { Morehead City and } \\
\text { Wilmington, NC }\end{array}$ & $300 \mathrm{~m}$ & $\begin{array}{c}4-10 \\
\text { minutes }\end{array}$ & Radar Reflectivity & SB event detection \\
\hline $\begin{array}{c}\text { Radiosondes (Wyoming } \\
\text { Weather, 2015) }\end{array}$ & Morehead City, NC & $\begin{array}{c}\text { Does not } \\
\text { apply }\end{array}$ & $\begin{array}{c}\text { 00Z and } \\
12 \mathrm{Z}\end{array}$ & CAPE, CIN and PWAT & $\begin{array}{c}\text { Characterize thermodynamic } \\
\text { environment of SB events }\end{array}$ \\
\hline $\begin{array}{c}\text { NARR Reanalysis } \\
\text { (NARR, 2015) }\end{array}$ & North America & $0.3^{\circ}$ & Daily & $\begin{array}{c}850 \mathrm{mb} \text { winds at } \\
34.36^{\circ} \mathrm{N}, 77.68^{\circ} \mathrm{W}\end{array}$ & $\begin{array}{c}\text { Characterize synoptic scale } \\
\text { winds during SB events }\end{array}$ \\
\hline NCEP Reanalysis & Global & $2.5^{\circ}$ & Daily & $\begin{array}{c}850 \mathrm{mb} \text { wind, SLP, } \\
\text { winds }\end{array}$ & $\begin{array}{c}\text { Characterize NASH } \\
\text { during SB events }\end{array}$ \\
\hline TRMM & $50^{\circ} \mathrm{N}-50^{\circ} \mathrm{S}$ & $0.25^{\circ}$ & Daily & $\begin{array}{c}\text { Characterize precipitation } \\
\text { distribution during SB days }\end{array}$ \\
\hline
\end{tabular}

Prepared by the authors.

The characterization of the thermodynamic environment of SB events was done using convective parameters obtained from the University of Wyoming Department of Atmospheric Science observed upperair radiosonde archive (Wyoming Weather, 2015). Namely, pre-calculated values of convective available potential energy (CAPE), convective inhibition (CIN) and precipitable water (PWAT) were collected from the 1200 UTC (0800 local time) Morehead City, NC (KMHX) atmospheric soundings. Together these three thermodynamic parameters play an important role in setting the stage for convection. CAPE represents the positive buoyancy energy available for convection and is therefore directly related to maximum updraft velocity and the potential for the occurrence of convection and precipitation (Wallace and Hobbs, 2006). CIN represents negative buoyancy energy, measuring the degree to which convection is inhibited by the presence of a stable layer or inversion at the top of the planetary boundary layer (Wallace and Hobbs, 2006). A higher value of CIN indicates a larger energy barrier must be overcome for thunderstorms to develop, typically via low-level forced ascent through a temperature inversion. Lastly, PWAT measures the depth of liquid water that would result from precipitating all of the water vapor in a vertical column of air over a given location, giving an indication for the upper limit on precipitation.

The classification of SB events according to synoptic-scale wind direction was done using the $0.3^{\circ}$ NARR (North American Regional Reanalysis) product. The $850 \mathrm{mb}$ level was chosen because it depicts the low-level synoptic scale flow within which the SB is embedded while minimizing surface effects (Azorin-Molina and Chen, 2009). Since the SB depth is typically $1-2 \mathrm{~km}$, it is reasonable to assume that the $850 \mathrm{mb}$ winds influences the evolution and propagation of SBs (Azorin-Molina and Chen, 2009; Banta, Olivies and Levinson, 1993; Helmis, Papadopoulos, Kalogiros, Soilemes and Asimakopoulos, 1995).

The synoptic-scale NASH climatology of winds, sea-level pressure (SLP) and precipitation was constructed using the high-resolution National Air and Space Administration (NASA) Tropical Rainfall Measuring Mission (TRMM) precipitation dataset and the National Center for Environmental Prediction (NCEP) Reanalysis from 2009-2012. The TRMM-3B42 is a daily merged infrared and microwave precipitation dataset that extends from $50^{\circ} \mathrm{S}$ to $50^{\circ} \mathrm{N}$ at $0.25^{\circ}$ resolution (Huffman et al., 2007). The NCEP Reanalysis (Kalnay et al., 1996) is a global, daily, $2.5^{\circ}$ horizontal resolution blend of observations and model data that includes, among many other variables, SLP, temperature, specific humidity, geopotential heights and horizontal winds at 17 vertical levels.

\subsection{Methods}

The first step of the analysis consisted of using the radar imagery to visually identify the presence of the SB fronts. This was followed by the classification of SB events according to precipitation and synoptic scale wind regime and the preparation of the SB dry and wet composites. A detailed description of the methods used in this analysis is presented below.

\section{$\underline{\text { SB Detection }}$}

SB fronts that occurred from May-September 2009-2012 were detected by subjective examination of NEXRAD Level II radar data from the Morehead City (KMHX) and Wilmington (KLTX) radar sites (figure 1). The detection of SB events was based on the following three criteria:

1. The SB thin line was clearly present in the radar reflectivity image. 
2. The SB thin line reflectivity values were between 5-15 dBZ (decibels relative to radar reflectivity).

3. The SB thin line propagated inland away from the coast.

The detection of SBs via radar-detected thin lines is a widely used and accepted method (Atlas, 1960; Simpson, Mansfield and Milford, 1977; Wakimoto and Atkins, 1994). The thin line method used here detects the stronger SB events, including all SB events that produce precipitation. Other studies have used satellite imagery to detect the line of SB convective clouds along the coast (e.g., Planchon, Damato, Dubreuil and Gouery, 2006), a method that detects only those SBs that produce clouds. Another more comprehensive method of SB detection is to analyze wind, temperature and moisture shifts using station data (Koch and Ray, 1997; Hughes, 2011; Frysinger, Lindner and Brueske, 2003). This method would likely result in a higher frequency of SB events because SB thin lines are typically only visible along strong SB fronts.

Figure 3. Radar reflectivity time series for the SB wet event on 14 June 2009 and the SB dry event on 21 July 2010

SB Wet (14 Jun 2009)
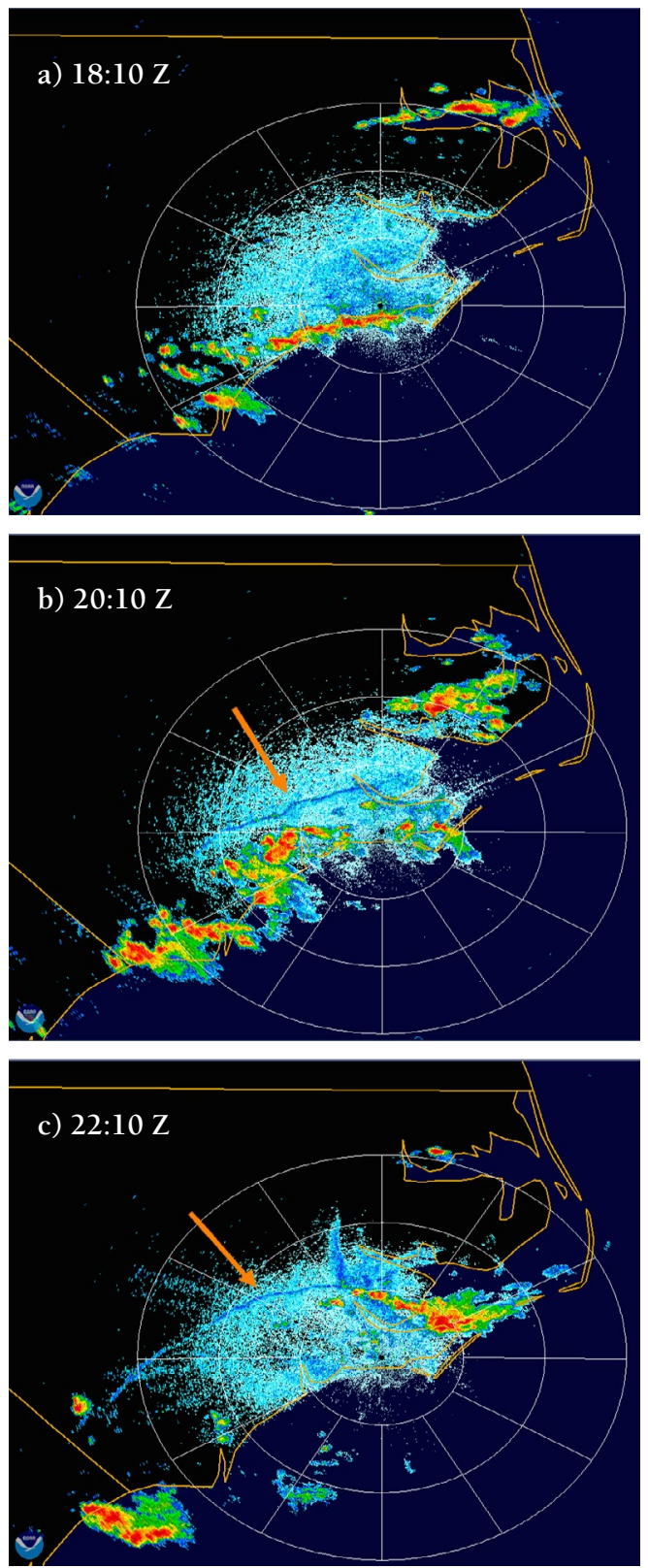

SB Dry (21 Jul 2010)
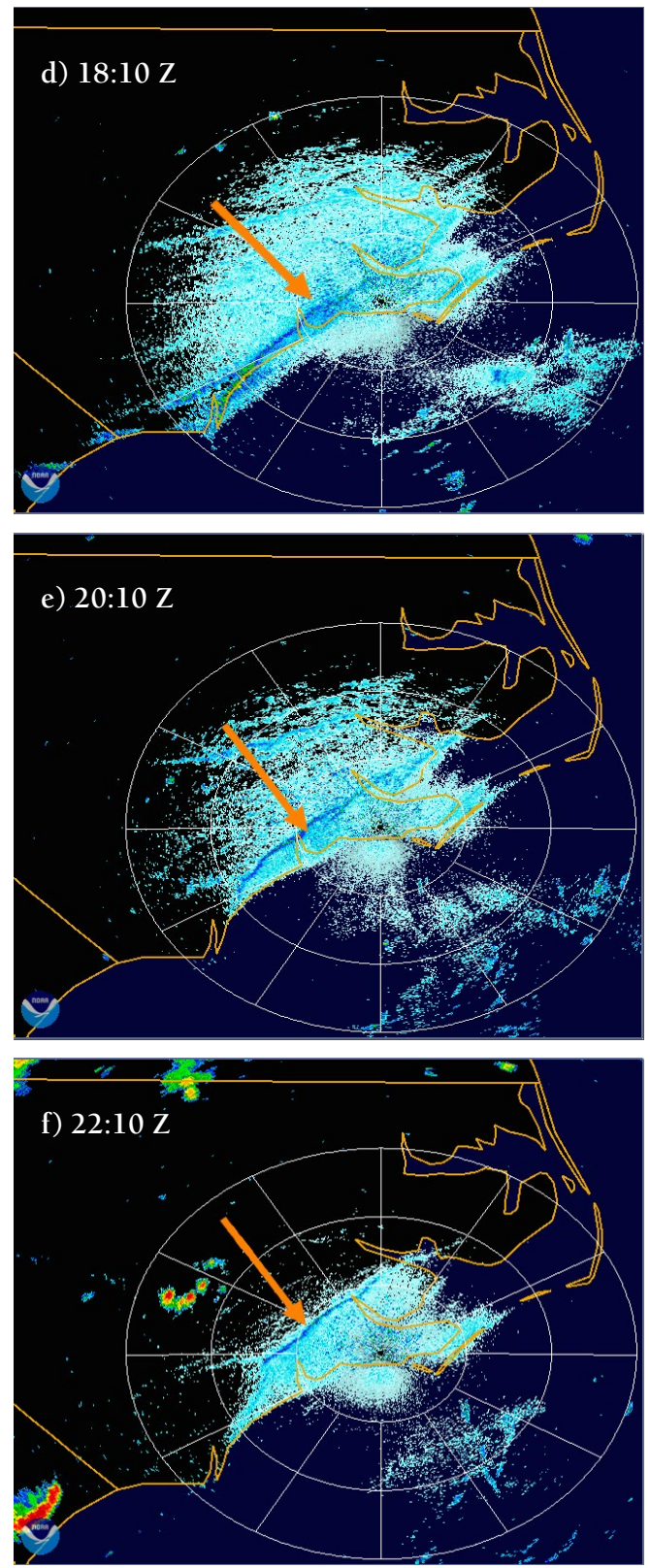

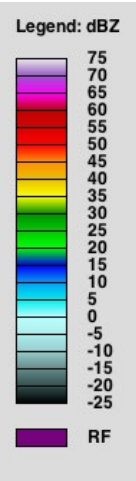

Thin line location is indicated by an orange arrow. Morehead City radar range rings at $50 \mathrm{~km}$ intervals are shown in white, with the radar site at the center.

Source: NOAA Climate Toolkit (NOAA 2015). Prepared by the authors. 
Two examples of SB thin lines in this study are shown in figure 3. The thin lines appear in dark blue in the radar imagery and their position is indicated by the orange arrows. On July 212010 a thin line formed in the morning along the coast (figure 3d) and propagated inland over the next few hours (figure 3e,f). This event did not produce any precipitation and was therefore classified as 'SB dry'. The North Carolina mesonet array of automated surface weather stations clearly shows the wind shift associated with the SB front on that day (figure 4). In the early morning the surface winds along the coast were from N-NW (figure 4a) and shifted to southeasterlies by the late afternoon as the SB front propagated inland (figure $4 \mathrm{~b}$ ). The 850 $\mathrm{mb}$ synoptic scale wind on that day as given by the NARR Reanalysis data at $34.36^{\circ} \mathrm{N}, 77.68^{\circ} \mathrm{W}$ (the point nearest Wilmington) was $9 \mathrm{~ms}^{-1}$ from the west-northwest, or offshore with respect to the NC coast. According to previous studies such strong offshore winds are not conducive for the formation of strong convergence and updrafts along the SB front (Arritt, 1993) and may be the reason why this SB did not produce precipitation. The radar sequence for the SB wet event example is shown in figure 3d-f. On June 142009 a thin line formed along the coast (figure $3 \mathrm{a}$ ) and propagated inland leaving behind a line of convection that remained close to the coast (figure $3 \mathrm{~b}, \mathrm{c}$ ). On this day the synoptic scale winds were also offshore. However, at $4 \mathrm{~ms}^{-1}$ the offshore winds fell well within the 2-6 $\mathrm{ms}^{-1}$ range that has been found to favor stronger SB updrafts and convergence (Arritt, 1993; Crosman and Horel, 2010), thereby favoring precipitation.

Figure 4. Surface winds from the North Carolina mesonet weather stations for the SB wet event on June 142009

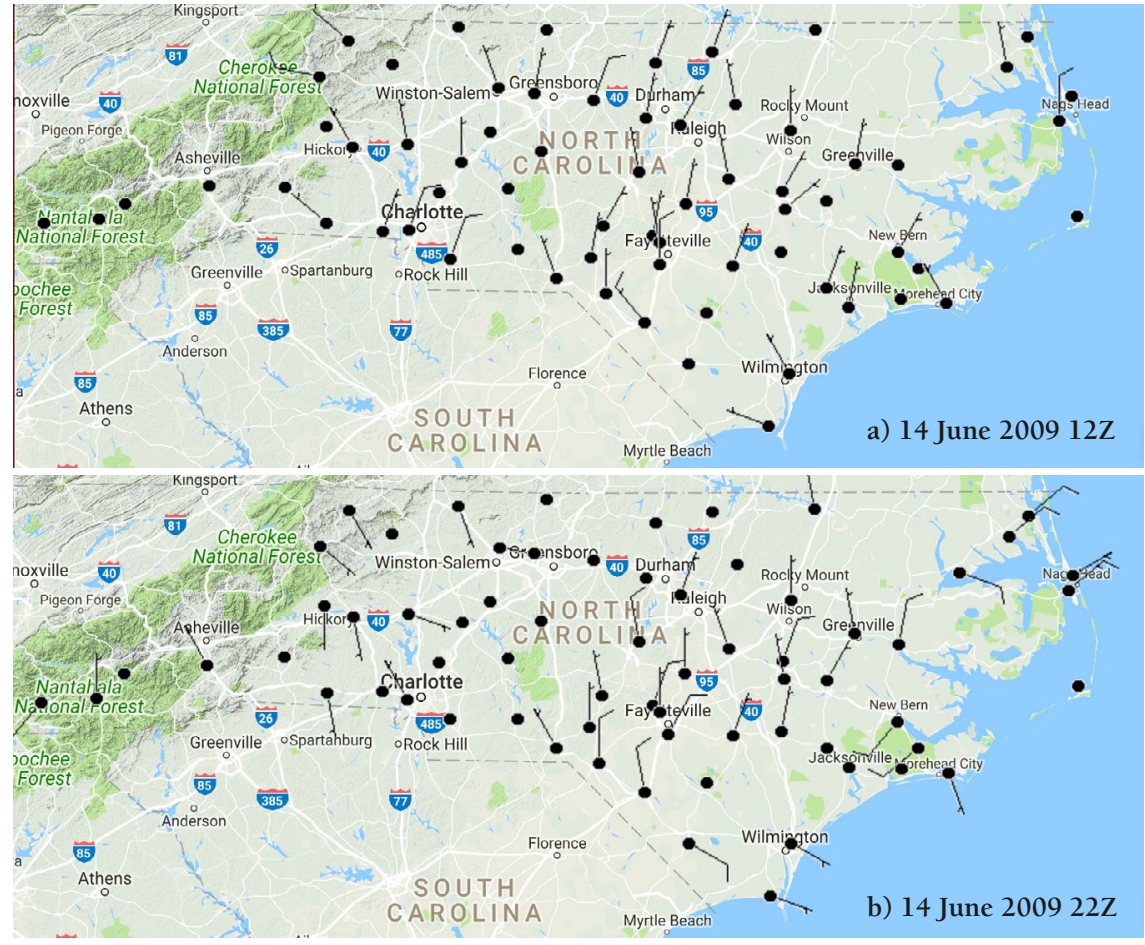

Source: MesoWest data display system (http://mesowest.utah.edu/).

\section{$\underline{\text { SB Classification }}$}

Each SB event detected above was next classified according to the absence/presence of precipitation and synoptic-scale wind direction.

Using the NEXRAD radar data, SB events were classified as either 'SB wet' or 'SB dry'. On any given summer day, diurnal convection not initiated by the SB front can occur in the vicinity of the SB. Therefore, a SB precipitation classification method similar to the one utilized by Boyles (2006) was used to distinguish between wet and dry events. An SB event was classified as wet if the following two criteria were met:

1. A precipitation band initially formed in the sea breeze zone during the afternoon hours and was approximately parallel to the coastline;

2. The precipitation band either propagated inland, or remained stationary for at least two hours before propagating elsewhere - usually to the northeast or back toward the coastline. 
SB dry events did not satisfy these conditions and did not experience any precipitation along the thin line at any time during the event.

In order to study the relationship between the synoptic-scale flow and SB precipitation, SB events were further classified according to the synoptic-scale wind direction. This analysis used the daily $850 \mathrm{mb}$ wind direction at the NARR gridpoint (at $34.36^{\circ} \mathrm{N}, 77.68^{\circ} \mathrm{W}$ ) that is nearest to the SB initiation zone between Wilmington and Morehead City, NC. Using the NARR $850 \mathrm{mb}$ winds, SB events were classified under one of the following four synoptic wind regimes as they relate to the orientation of the coast: 'offshore', 'onshore', or 'parallel'. Given the northeast-southwest orientation of the NC coast to the south of Wilmington, when the synoptic-scale wind was from 0-90 or 180-270 degrees the SB event was classified as parallel. SB events that occurred under synoptic-scale winds from 90-180 degrees (270-360 degrees) were classified as onshore (offshore). In addition to direction, wind speeds were also catalogued for each SB event.

\section{Composite Analysis}

Finally, averages of daily TRMM precipitation and NCEP Reanalysis sea-level pressure and $850 \mathrm{mb}$ winds for SB wet and SB dry events were used to create composites of the synoptic-scale conditions during those events.

\section{Results}

A total of 88 SB events were detected during the months of May-September 2009-2012 (Table 2). About $80 \%$ of SB events occurred during June-August with a maximum in July. SB events developed on 14\% of the days from May-September. This percentage is considerably lower than that of a previous climatology by Koch and Ray (1997) that reported SB development on $88 \%$ of the days in the months of May-September. This is likely due to the fact that Koch and Ray (1997) utilized a combination of radar, weather station and satellite data to construct their SB climatology and were therefore able to capture weaker, non-precipitating SBs that may not have been visible as a thin line reflectivity signature.

Table 2. List of SB events detected during 2009-2012

\begin{tabular}{|c|c|c|c|c|c|c|c|}
\hline \multicolumn{8}{|c|}{ SB EVENTS (2009-2012) } \\
\hline \multicolumn{2}{|c|}{2009} & \multicolumn{2}{|c|}{2010} & \multicolumn{2}{|c|}{2011} & \multicolumn{2}{|c|}{2012} \\
\hline Date & Wind & Date & Wind & Date & Wind & Date & Wind \\
\hline $5 / 29$ & VAR & $5 / 22$ & PAR & $5 / 22$ & OFF & $5 / 1$ & OFF \\
\hline $6 / 2$ & PAR & $5 / 27$ & PAR & $5 / 24$ & OFF & $5 / 21$ & $\mathrm{ON}$ \\
\hline $6 / 10$ & PAR & $5 / 29$ & ON & $5 / 25$ & OFF & $5 / 28$ & ON \\
\hline $6 / 12$ & OFF & $5 / 30$ & OFF & $5 / 31$ & PAR & $5 / 31$ & OFF \\
\hline $6 / 14$ & OFF & $6 / 2$ & OFF & $6 / 1$ & PAR & $6 / 19$ & PAR \\
\hline $6 / 23$ & PAR & $6 / 9$ & OFF & $6 / 3$ & OFF & $6 / 21$ & PAR \\
\hline $6 / 29$ & OFF & $6 / 11$ & OFF & $7 / 10$ & PAR & $6 / 25$ & OFF \\
\hline $6 / 30$ & OFF & $6 / 12$ & PAR & $7 / 21$ & OFF & $7 / 4$ & OFF \\
\hline $7 / 1$ & OFF & $6 / 13$ & OFF & $7 / 22$ & OFF & $7 / 8$ & OFF \\
\hline $7 / 15$ & PAR & $6 / 15$ & OFF & $7 / 27$ & PAR & $7 / 9$ & OFF \\
\hline $7 / 19$ & PAR & $6 / 17$ & OFF & $7 / 28$ & OFF & $7 / 11$ & OFF \\
\hline $7 / 21$ & PAR & $6 / 19$ & VAR & $7 / 29$ & OFF & $7 / 12$ & VAR \\
\hline $7 / 22$ & ON & $6 / 20$ & OFF & $8 / 2$ & PAR & $7 / 13$ & $\mathrm{ON}$ \\
\hline $7 / 24$ & PAR & $6 / 21$ & OFF & $8 / 17$ & VAR & $7 / 14$ & ON \\
\hline $7 / 25$ & PAR & $6 / 22$ & OFF & $8 / 23$ & VAR & $7 / 19$ & OFF \\
\hline $7 / 30$ & PAR & $6 / 24$ & OFF & $8 / 24$ & ON & $7 / 26$ & OFF \\
\hline $7 / 31$ & PAR & $6 / 28$ & PAR & & & $8 / 18$ & OFF \\
\hline $8 / 1$ & PAR & $7 / 10$ & OFF & & & $9 / 7$ & PAR \\
\hline $8 / 4$ & OFF & $7 / 11$ & OFF & & & $9 / 12$ & $\mathrm{ON}$ \\
\hline $8 / 8$ & OFF & $7 / 13$ & PAR & & & & \\
\hline $8 / 10$ & OFF & $7 / 19$ & OFF & & & & \\
\hline $8 / 19$ & PAR & $7 / 21$ & OFF & & & & \\
\hline $8 / 26$ & PAR & $7 / 23$ & OFF & & & & \\
\hline $8 / 29$ & OFF & $8 / 8$ & PAR & & & & \\
\hline $8 / 30$ & PAR & $8 / 10$ & OFF & & & & \\
\hline & & $8 / 12$ & OFF & & & & \\
\hline & & $9 / 4$ & OFF & & & & \\
\hline & & $9 / 14$ & OFF & & & & \\
\hline
\end{tabular}

Green indicates SB wet events and brown indicates SB dry events. The $850 \mathrm{mb}$ synoptic-scale wind for each case is listed as follows: VAR-Variable, PAR-Parallel, OFF-Offshore, ON-Onshore.

Prepared by the authors. 
Of the total 88 detected SB events about half, or 41 events, were classified as SB wet events. The remaining 47 events were classified as SB dry events. The following is an analysis of the atmospheric conditions (wind speed and direction, CAPE, CIN and NASH location) that characterize SB wet and SB dry events.

\subsection{Synoptic-Scale Wind Direction and Speed}

As shown in Table 3, among the 41 SB wet events, 17 (42\%) occurred under offshore synoptic scale flow, 12 (29\%) occurred under parallel synoptic flow, 7 (17\%) occurred under onshore flow and 5 (12\%) occurred under variable wind flow. Since offshore flow can induce a strong SB circulation and strong convergence along the SB front (e.g., Arritt, 1993), the prevalence of wet SB events during offshore flow is not surprising. The small number of observed SB wet events during onshore flow is also in line with previous modeling studies that found that onshore flow leads to weak convergence along the SB front (e.g., Arritt, 1993). A total of 12 SB wet events occurred during parallel flow. The majority of those SB wet parallel flow events (10 of 12) occurred during days when the flow was from the southwest and can be defined as corkscrew sea breeze events (Adams, 1997). The fact that most of the SB wet parallel flow events in this study are classified as corkscrew corroborates theoretical and modeling studies that indicate that corkscrew SB are stronger and likely conducive to precipitation (Steele et al., 2014).

Table 3. Numbers of SB wet and dry events in each wind category

\begin{tabular}{lccccc}
\hline & Offshore & Onshore & Parallel & Variable & Total \\
\hline SB wet & 17 & 7 & 12 & 5 & 41 \\
SB dry & 30 & 1 & 16 & 0 & 47 \\
Total & 47 & 8 & 28 & 5 & 88 \\
\hline
\end{tabular}

Prepared by the authors.

In contrast, among the 47 SB dry events, 30 (64\%) occurred under offshore synoptic flow, 16 (34\%) under parallel flow and 1 (2\%) under onshore flow. The majority of SB dry parallel flow events (10 of 16) can be defined as backdoor (Adams, 1997) because they occurred during days when the synoptic-scale flow was from the northwest. The fact that most of the SB dry parallel flow events in this study are classified as backdoor agrees well with the hypothesis that backdoor SB are weaker and less conducive to precipitation than their corkscrew counterparts (Steele et al., 2014).

Since the majority of SBs, wet and dry, occurred during offshore flow, the question remains as to what caused the difference in precipitation regime. The analysis that follows investigates the possible role of synoptic-scale wind speeds.

Table 4 displays the average wind speeds associated SB dry and SB wet events. The average offshore synoptic scale flow during the SB wet events $\left(4.47 \pm 1.28 \mathrm{~ms}^{-1}\right)$ was weaker than that of the SB dry events $\left(6.47 \pm 2.3 \mathrm{~ms}^{-1}\right)$. This difference was statistically significant at the $95 \%$ confidence level. The stronger wind speeds during the SB dry events that occurred during offshore synoptic scale flow were above the optimal range likely causing a weakened SB front with a lower potential for precipitation.

The average wind speed for the 12 SB wet parallel wind direction events was not statistically different from the average wind speed for the 16 SB dry parallel wind direction events. The results presented here suggest that during SB events that occur during days when the wind is parallel to the coast, the wind direction (or whether it is corkscrew or backdoor) may play a more important role on SB precipitation than the wind speed.

Table 4. Statistical comparison of the synoptic-scale wind speeds during the SB dry and SB wet events for each of the synoptic-scale wind directions

\begin{tabular}{lccccc}
\hline & Onshore $\left(\mathrm{ms}^{-1}\right)$ & Offshore $\left(\mathrm{ms}^{-1}\right)$ & Parallel $\left(\mathrm{ms}^{-1}\right)$ & Variable $\left(\mathrm{ms}^{-1}\right)$ & All $\left(\mathrm{ms}^{-1}\right)$ \\
\hline SB Dry Events $(\mathrm{N}=47)$ & $2.00(\mathrm{~N}=1)$ & $6.47 \pm 2.30(\mathrm{~N}=30)$ & $5.63 \pm 2.31(\mathrm{~N}=16)$ & $(\mathrm{N}=0)$ & $6.00 \pm 2.36$ \\
SB Wet Events $(\mathrm{N}=41)$ & $2.85 \pm 0.89(\mathrm{~N}=7)$ & $4.47 \pm 1.28(\mathrm{~N}=17)$ & $5.25 \pm 2.77(\mathrm{~N}=12)$ & $1.34 \pm 1.50(\mathrm{~N}=4)$ & $4.02 \pm 2.16$ \\
\hline
\end{tabular}

Bold numbers represent categories in which the differences between the winds during SB Dry and SB Wet events are statistically significant at the $95 \%$ confidence level according to the Student's t-test.

Prepared by the authors. 
The average wind speed for the $7 \mathrm{SB}$ wet onshore wind direction events was $2.86 \pm 0.9 \mathrm{~ms}^{-1}$. According to previous studies (e.g. Arrit, 1993; Gilliam et al., 2004), in order for SBs to form on onshore flow days the onshore wind speeds have to be very light. Any onshore wind speeds greater than $2-4 \mathrm{~ms}^{-1}$ significantly diminish the SB front and associated vertical velocities across the front. All 7 SB wet onshore synoptic wind events fall within this weak wind speed range.

When comparing the frequency of $850 \mathrm{mb}$ wind speeds across all synoptic-scale wind directions (offshore, onshore, parallel, variable) for all of the 88 SB events, results suggest that on average, SB dry events tend to occur under stronger synoptic-scale wind speeds $\left(6.00 \pm 2.36 \mathrm{~ms}^{-1}\right)$ while SB wet events tend to occur under lighter synoptic-scale wind speeds $\left(4.02 \pm 2.16 \mathrm{~ms}^{-1}\right)$. This is in good agreement with previous studies (e.g. Arrit, 1993; Gilliam et al., 2004) that showed that SBs that form under lighter synoptic-scale flow, that is still strong enough to induce convergence and frontogenesis, can have enhanced upward vertical velocities along the SB front and produce precipitation.

In summary the observations presented here show that most SBs (wet and dry) in the NC coast (85\%) occurred during light flow that is offshore or parallel to the coast. Only a few SBs (9\%) occurred during onshore flow. A novel finding is that SBs that occurred during parallel flow with a southwesterly component, also known as corkscrew SBs, were more likely to produce precipitation than SBs that occurred during parallel flow with a northwesterly component, the so called backdoor SB.

\subsection{Thermodynamics}

Table 5 displays the mean and standard deviation of thermodynamic variables derived from the 1200 UTC atmospheric Morehead City (KMHX) soundings for SB wet and SB dry events. Ideally, a 1800 UTC atmospheric sounding analysis would be preferred, but the National Weather Service rarely launches at that time. The 1200 UTC atmospheric soundings are still valuable because they capture the atmosphere as it warms in the morning hours. The average CAPE for the 41 SB wet events in this climatology was $1187.24 \pm 846.2 \mathrm{~J} / \mathrm{kg}$, typical for moderate instability and thunderstorm activity. In contrast, the average CAPE over the $47 \mathrm{SB}$ dry events was $860.85 \pm 861.03 \mathrm{~J} / \mathrm{kg}$, a value consistent with weaker instability and less frequent thunderstorm activity. The difference in average CAPE between the SB wet and SB dry events was statistically significant at the $90 \%$ confidence level.

Table 5. Mean and standard deviation of thermodynamic variables for SB dry and SB wet events

\begin{tabular}{cccc}
\hline & CAPE $(\mathrm{J} / \mathrm{kg})$ & CIN $(\mathrm{J} / \mathrm{kg})$ & PWAT $(\mathrm{mm})$ \\
\hline SB Dry Events $(\mathrm{N}=47)$ & $860.85 \pm 861.03$ & $93.54 \pm 105.34$ & $40.91 \pm 10.90$ \\
SB Wet Events $(\mathrm{N}=41)$ & $1187.24 \pm 846.20$ & $44.72 \pm 52.78$ & $43.92 \pm 8.28$ \\
\hline
\end{tabular}

Bold values indicate that the difference between the mean values for SB dry and SB wet events is statistically significant at the 90\% confidence level.

$$
\text { Prepared by the authors. }
$$

Another thermodynamic variable commonly used to measure thunderstorm potential is CIN, which measures the barrier of negative buoyancy that must be overcome for an air parcel to reach the level of free convection. CIN values in the range of 50 to 200 typically require strong heating and synoptic scale forcing to break through stable air aloft and initiate convection and precipitation. Based on these results the amount of early morning stable air, as a measure of CIN, could potentially be an indicator of whether or not an SB event will induce precipitation. In the case of high early morning CIN, the SB front would likely need to be rather strong with robust updrafts to break through the stable air above in order to tap into instability and induce precipitation. The average CIN for the SB wet events was $44.72 \pm 52.78 \mathrm{~J} / \mathrm{kg}$ whereas the average CIN for the SB dry events was much larger at $93.65 \pm 105.34 \mathrm{~J} / \mathrm{kg}$. The difference in average CIN between the SB wet and SB dry events was statistically significant at the $95 \%$ confidence level. There were also 14 SB dry events with CIN values that were higher than $150 \mathrm{~J} / \mathrm{kg}$ and therefore totally unfavorable for convection. The average values of PWAT were very similar in SB wet and SB dry events, indicating that there was always enough moisture in the atmosphere to produce convection.

In summary, the thermodynamic results above suggest that high CAPE and low CIN in the early morning are favorable for the occurrence of a wet SB event. 


\subsection{Influence of the NASH}

The analysis above shows that when compared to SB dry events, the SB wet events are characterized by higher CAPE, lower CIN and generally weaker winds that are offshore or parallel to the coast. In order to examine the large-scale context within which the SB evolves, composites of the NCEP Reanalysis $850 \mathrm{mb}$ winds, SLP and TRMM precipitation for SB wet and SB dry events are shown in figure 5. The NCEP Reanalysis was chosen because it is a global dataset and it therefore captures the entire extent of the NASH. As seen in figure 5, the NASH is the dominant feature of the summertime flow over the Atlantic and SE U.S. The NASH western ridge controls the direction and strength of the winds along the NC coast and the longitude of the moisture laden southerly jet that feeds convection and precipitation in the SE US.

Figure 5. Composite maps for a) SB wet and b) SB dry.

\section{Sea breeze composites}

TRMM Precipitation/NCEP $850 \mathrm{mb} U, \mathrm{~V}$, SLP

\section{SB Wet (41 Events)}

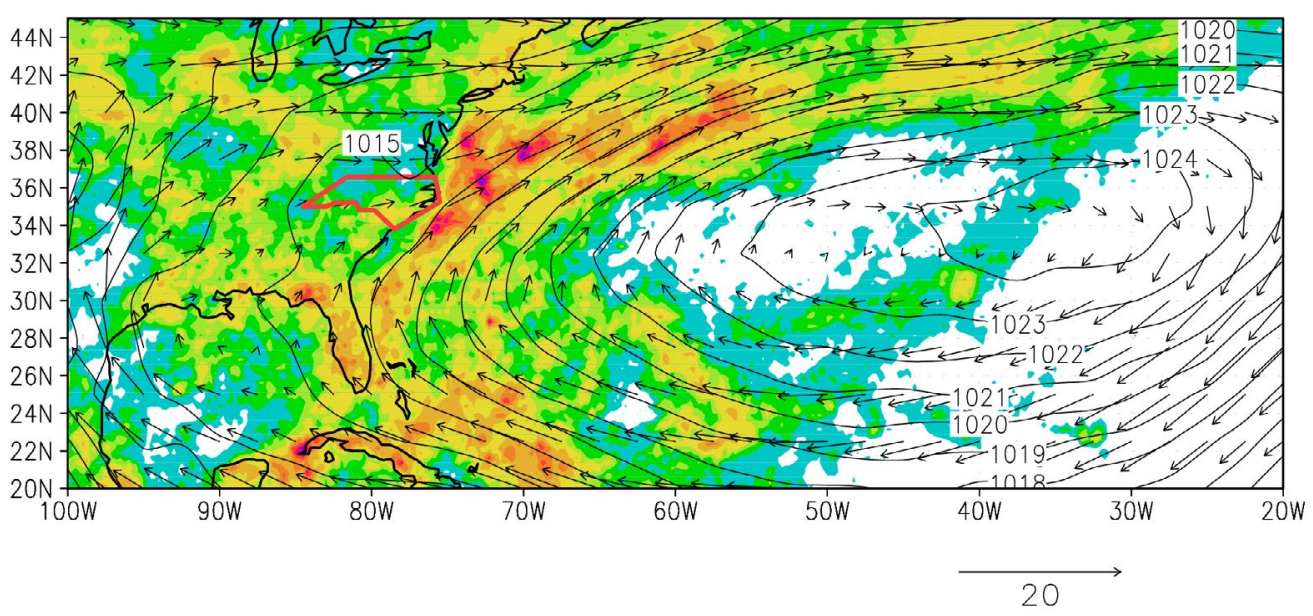

\section{SB Dry (47 Events)}

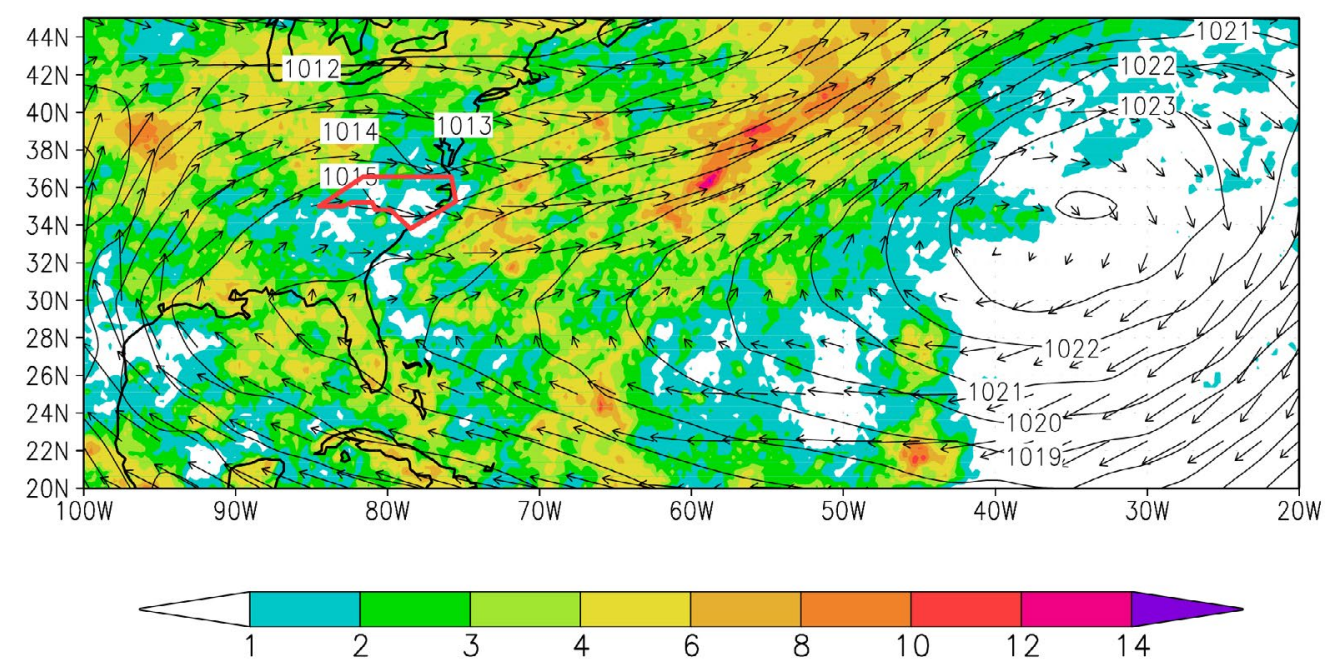

The composite maps display NCEP Reanalysis sea level pressure (hPa), $850 \mathrm{mb}$ winds $\left(\mathrm{ms}^{-1}\right)$ and precipitation $\left(\mathrm{mm} \mathrm{day}^{-1}\right)$ measured by the Tropical Rainfall Measuring Mission (TRMM). The map of North Carolina is shown in red. The $20 \mathrm{~ms}^{-1}$ wind vector and precipitation colorbar in $\mathrm{mm}$ are also shown.

Data source: TRMM, NCEP Reanalysis datasets. Prepared by the authors. 
In both composites the center of the NASH was located at about the same position in the central North Atlantic. In the SB wet composite (figure 5a) the NASH western ridge and its associated southwesterly winds were located near the US eastern seaboard. This means that the winds along the coast of NC were more parallel to the coast. The presence of the moisture laden southwesterly winds over the SE U.S. favored the occurrence of precipitation (figure 5a) over the entire region, including the domain of the sea breeze in NC. In the SB dry composite on the other hand, the NASH western ridge extended further inland so that its associated southwesterly winds carried moisture into the US Great Plains (figure 5b) leaving higher SLP, stronger offshore winds and drier conditions over the SE US, including the NC coast. These results indicate that the location of the NASH western ridge plays an important role in modulating the winds and precipitation in the SB along the NC coast. A closer analysis of the TRMM data (not shown) reveals that for the 2009-2012 period SB wet days were responsible for about $20-30 \%$ of the total May-September precipitation along the NC coast.

In summary, the location of the NASH western ridge plays a role in setting up the synoptic scale winds that control SB precipitation, both via changes in wind direction and speed and changes in advection of the warm, moist air that fuels convection in the SB.

\section{Discussion}

Previous studies showed that the direction and strength of the synoptic-scale wind are the most influential factors in determining SB development, propagation, intensity, arrival time and termination (Arritt, 1993; Atkins and Wakimoto, 1997; Azorin-Molina and Chen, 2009; Gilliam et al., 2004). This study uses radar, satellite, radiosonde and reanalysis data to investigate local and remote conditions that favor the occurrence of precipitation in SB events in NC. The SB was present $14 \%$ of the days. A total of 88 SB events were detected along the coast of NC between May-September 2009-2012 using the NEXRAD radar database. Events were classified according to whether or not they produced precipitation into SB wet ( $47 \%$ of all events) or SB dry (53\% of all events). Local statistics and large-scale composites of thermodynamic and dynamic variables were calculated for the two SB categories. SB wet days were responsible for about $20-30 \%$ of the total May-September precipitation along the NC coast.

Analysis of the synoptic scale wind direction during SB events showed that, in good agreement with previous work, most SBs occurred during days of offshore or parallel flow (85\% of all events). A few SBs (9\%) occurred during light onshore flow and the remaining occurred during calm days. An interesting and novel finding of this study is that it provides observational evidence for the results of previous studies of the SB evolution during parallel flow. Previous studies (Adams, 1997; Steele et al., 2014) showed that northern hemisphere SBs that form during synoptic-scale flow that is parallel to the coast with land to the right (left) tend to have weaker (stronger) convergence along the SB front. In NC this means that SBs that occurred during parallel synoptic scale flow with a southwesterly component, known as corkscrew SBs, would have a stronger SB front and thus would be more likely to produce precipitation than SBs that occurred during parallel flow with a northeasterly component, the so-called backdoor SB. In this study most of the corkscrew events ( 10 of 12 events) were SB wet while most of the backdoor events (10 of 16 events) were SB dry, thus supporting the findings of previous work.

Analysis of the speed of synoptic scale winds during SB wet and SB dry events showed significant differences between SB wet and SB dry events. In particular, the light synoptic-scale winds $\left(4.02 \pm 2.16 \mathrm{~ms}^{-1}\right)$ during SB wet events likely allowed the development of a strong SB that favored precipitation. On the other hand, the synoptic scale winds during SB dry events was significantly stronger $\left(6.00 \pm 2.36 \mathrm{~ms}^{-1}\right)$ and just outside the optimal wind speed for the formation of a strong SB. All SB wet events that occurred during periods of onshore winds fell within the optimal onshore synoptic-scale wind range of 0-4 $\mathrm{ms}^{-1}$. No SB dry events occurred during onshore synoptic-scale flow.

The thermodynamic parameter analysis suggests that in the value of early morning CAPE also plays a role in whether or not an existing SB front will initiate convection and precipitation. Significantly larger CAPE values were present during SB wet events than during SB dry events indicating a better potential for the formation of deep thunderstorms in the SB wet events. In addition to that, CIN was significantly smaller during SB wet events than during SB dry events, again indicating a better potential for the formation of deep thunderstorms during SB wet events. Combined CIN and CAPE can be useful to identify 
the likelihood of a SB front inducing precipitation later in the day. The values of PWAT were very similar during SB wet and SB dry events indicating that moisture was always available for convection to occur.

Finally, the location of the NASH western ridge was found to be an important remote control on the important parameters that control SB development and precipitation because it controls both the location of the jet that draws warm, moist, high CAPE air northward from the tropics and the strength and direction of the synoptic-scale flow along the coast. As such, the location of the NASH western ridge may be the overarching parameter that controls precipitation in the NC SB.

\section{Conclusions}

Results from this SB climatology suggest that an interplay of optimal thermodynamic and synoptic-dynamic conditions must be present for a NC SB front to induce precipitation on any given SB day. This study shows that the best conditions for the NC SB to induce precipitation would occur with enhanced early morning instability, minimal stable air aloft and synoptic scale winds that are from the W-SW at about $4 \mathrm{~ms}^{-1}$. Those conditions are favored when the NASH western ridge is present near the SE US coastline, allowing for synoptic-scale wind that is offshore or parallel to the coast and brings plentiful moisture to the SE US.

Over the past few decades the NASH western ridge has slowly moved westward, a trend that has been shown to continue as the climate warms ( $\mathrm{Li}, \mathrm{Li}, \mathrm{Fu}$, Deng and Wang, 2011). A future study should investigate whether this westward propagation of the NASH western ridge has caused a concomitant downward trend of the SB precipitation over the past few decades. The question of whether a possible continued westward shift of the NASH western ridge may cause a decrease of precipitation in the NC SB as the climate changes also needs to be investigated.

\section{Acknowledgements}

This project was partially funded by the Climate and Large-Scale Dynamics and the Physical and Dynamic Meteorology programs of the National Science Foundation's Division of Atmospheric and Geospatial Sciences, Award AGS-1118141. We would like to thank the three anonymous reviewers whose comments helped us improve the manuscript.

\section{References}

Adams, E. (1997). Four ways to win the sea breeze game, Sailing World, March, 44-49.

Arritt, R. W. (1993). Effects of the large-scale flow on characteristic features of the sea breeze. Journal of Applied Meteorology, 32(1), 116-125. https://doi.org/10.1175/1520-0450(1993)032<0116:EOTLSF>2.0.CO;2

Atkins, N. T. \& Wakimoto, R. M. (1997). Influence of the synoptic-scale flow on sea breezes observed during CaPE. Monthly Weather Review, 125(9), 2112-2130. https://doi.org/10.1175/15200493(1997) 125<2112:IOTSSF>2.0.CO;2

Atlas, D. (1960). Radar detection of the sea breeze.J. Meteorology, 17, 244-258. https://doi.org/10.1175/15200469(1960)017<0244:RDOTSB>2.0.CO;2

Azorin-Molina, C. \& Chen, D. (2009). A climatological study of the influence of synoptic-scale flows on sea breeze evolution in the Bay of Alicante (Spain). Theoretical and Applied Climatology, 96(3-4), 249-260. https://doi.org/10.1007/s00704-008-0028-2

Azorin-Molina, C., Tijm, S., Ebert, E. E., Vicente-Serrano, S.M. \& Estrela M.J. (2015) High Resolution HIRLAM Simulations of the Role of Low-Level Sea-Breeze Convergence in Initiating Deep Moist Convection in the Eastern Iberian Peninsula. Boundary Layer Meteor. 154(1), 81-100. https://doi. org/10.1007/s10546-014-9961-z

Banta, R. M., Olivier, L. D. \& Levinson, D. H. (1993). Evolution of the Monterey Bay sea-breeze layer as observed by pulsed Doppler lidar. Journal of the Atmospheric Sciences, 50(24), 3959-3982. https:// doi.org/10.1175/1520-0469(1993)050<3959:EOTMBS>2.0.CO;2

Bechtold, P., Pinty, J. P. \& Mascart, F. (1991). A numerical investigation of the influence of large-scale winds on sea-breeze-and inland-breeze-type circulations. Journal of Applied Meteorology, 30(9), 1268-1279. https://doi.org/10.1175/1520-0450(1991)030<1268:ANIOTI>2.0.CO;2 
Boyles, R. (2006). Investigation of Mesoscale Precipitation Processes in the Carolinas Using a Radarbased Climatology. Doctoral Dissertation, Department of Marine, Earth and Atmospheric Sciences, North Carolina State University. Retrieved from http://www.lib.ncsu.edu/resolver/1840.16/3895

Carlson, G. S. (2009). Spatial and temporal patterns of summer season precipitation across the Carolina coastal region (Doctoral dissertation, The University of North Carolina, Chaper Hill).

Crosman, E. T. \& Horel, J. D. (2010). Sea and lake breezes: a review of numerical studies. Boundary-Layer Meteorology, 137(1), 1-29. https://doi.org/10.1007/s10546-010-9517-9

Curtis, S. (2006). Developing a Climatology of the South's 'Other' Storm Season: ENSO Impacts on Winter Extratropical Cyclogenesis. Southeastern Geographer, 46(2), 2006, 231-244. Project MUSE. https://doi. org/10.1353/sgo.2006.0021

Diem, J. (2006). Synoptic-scale controls of summer precipitation in the Southeastern United States. Journal of Climate, 19, 613-621. https://doi.org/10.1175/JCLI3645.1

Estoque, M.A. (1962). The sea breeze as a function of the prevailing synoptic situation. J. Atmos. Sci., 19, 244-250. https://doi.org/10.1175/1520-0469(1962)019<0244:TSBAAF>2.0.CO;2

Frysinger, J. A., Lindner, B. L. \& Brueske, S. L. (2003). Statistical Sea-Breeze Prediction Algorithm for Charleston, South Carolina, Wea. Forecasting, 18, 614-625. https://doi.org/10.1175/15200434(2003)018<0614:ASSPAF>2.0.CO;2

Fuhrmann, C. M., Konrad, C. E., Kovach, M. M. \& Perkins, D. J. (2011). The August 2007 heat wave in North Carolina: Meteorological factors and local variability. Physical Geography, 32(3), 217-240. http://www.tandfonline.com/doi/abs/10.2747/0272-3646.32.3.217

Gilliam, R. C., Raman, S. \& Niyogi, D. D. S. (2004). Observational and numerical study on the influence of large-scale flow direction and coastline shape on sea-breeze evolution. Boundary-Layer Meteor., 111(2), 275-300. https://doi.org/10.1023/B:BOUN.0000016494.99539.5a

Gil Olcina, A. \& Olcina Cantos, J. (2017). Tratado de climatología. Instituto Interuniversitario de Geografía, Publicacions Universitat D'Alacant.

Helmis, C. G., Papadopoulos, K. H., Kalogiros, J. A., Soilemes, A. T., \& Asimakopoulos, D. N. (1995). Influence of background flow on evolution of Saronic Gulf sea breeze. Atmospheric Environment, 29(24), 3689-3701. https://doi.org/10.1016/1352-2310(95)00008-M

Huffman, G. J., Adler, R. F., Bolvin, D. T., Gu, G., Nelkin, E.J., Bowman, K.P., Hong, Y., (...) \& Wolff, D. B. (2007). The TRMM multi-satellite precipitation analysis: quasi-global, multi-year, combined-sensor precipitation estimates at fine scale. J. Hydrometeor. 8(1): 38-55. https://doi.org/10.1007/978-90-4812915-7_1

Hughes, C. (2011). The climatology of the Delaware Bay/sea breeze. (Masters of Science Thesis, University of Delaware).

Jacobs, N. A., Lackmann, G. M. \& Raman, S. (2005). The combined effects of Gulf stream-induced baroclinicity and upper-level vorticity on U.S. East Coast extratropical cyclogenesis. Mon. Weather Rev., 133, 2494-2501. https://doi.org/10.1175/MWR2969.1

Kalnay, E., Kanamitsu, M., Kistler, R., Collins, W., Deaven, D., Gandin, L., Iredell, M., (...) \& Joseph D. (1996). The NCEP/NCAR 40-year reanalysis project. Bulletin of the American Meteorological Society, 77: 437-472. https://doi.org/10.1175/1520-0477(1996)077<0437:TNYRP>2.0.CO;2

Kingsmill, D. E. (1995). Convection initiation associated with a sea-breeze front, a gust front and their collision. Mon. Wea. Rev., 123, 2913-2933. https://doi.org/10.1175/1520-0493(1995)123<2913:CIA WAS>2.0.CO;2

Koch, S. E. \& Ray, C. A. (1997). Mesoanalysis of summertime convergence zones in central and eastern North Carolina. Wea. Forecasting, 12(1), 56-77. https://doi.org/10.1175/1520-0434(1997)012<0056:MOSC $\underline{\mathrm{ZI}>2.0 . \mathrm{CO} ; 2}$

Larson, J., Zhou, Y. \& Higgins, R. W. (2005). Characteristics of landfalling tropical cyclones in the United States and Mexico: Climatology and interannual variability. J. Climate, 18, 1247-1262. https://doi. org/10.1175/JCLI3317.1 
Li, W., Li, L., Fu, R., Deng, Y. \& Wang, H. (2011). Changes to the North Atlantic subtropical high and its role in the intensification of summer rainfall variability in the southeastern United States. J. Climate, 24(5), 1499-1506. https://doi.org/10.1175/2010JCLI3829.1

Li, L., Li, W. \& Kushnir, Y. (2012). Variation of the North Atlantic subtropical high western ridge and its implication to Southeastern US summer precipitation. Climate Dynamics, 39(6), 1401-1412. https:// doi.org/10.1007/s00382-011-1214-y

Lyons, W. A. \& Olsson, L. E. (1973). Detailed Mesometeorological Studies of Air Pollution Dispersion in the Chicago Lake Breeze. Mon. Wea. Rev., 101(5), 387-403. https://doi.org/10.1175/15200493(1973)101<0387:DMSOAP>2.3.CO;2

Miller, S. T. K., Keim, B. D., Talbot, R. W. \& Mao, H. (2003). Sea breeze: Structure, forecasting and impacts. Reviews of Geophysics, 41(3). https://doi.org/10.1029/2003RG000124

Naor, R., Potchter, O., Shafir, H. \& Alpert, P. (2017). An observational study of the summer Mediterranean Sea breeze front penetration into the complex topography of the Jordan Rift Valley. Theor. and Appl. Climatol., 127 (1-2), 275-284. https://doi.org/10.1007/s00704-015-1635-3

National Climatic Data Center (NCEI) (2015). NEXRAD Data Inventory Search INational Centers for Environmental Information. Retrieved from http://www.ncdc.noaa.gov/nexradinv/map.jsp

National Oceanic and Atmospheric Administration (NOAA), Weather and Climate Toolkit. (2015). Retrieved from https://www.ncdc.noaa.gov/wct/

Nieto-Ferreira, R., Hall L. \& Rickenbach, T.M. (2013). A climatology of the structure, evolution and propagation of midlatitude cyclones in the Southeastern United States. J. Climate, 26, 8406-8421. https://doi.org/10.1175/JCLI-D-12-00657.1

Nieto-Ferreira, R., Hall, L. \& Rickenbach, T. M. (2015). Midlatitude cyclones in the southeastern United States: frequency and structure differences by cyclogenesis region. Int. J. Climatol. https://doi. org/10.1002/joc. 4247

North American Regional Reanalysis (2015). Retrieved from http://www.emc.ncep.noaa.gov/mmb/rreanl/ narr.bams.Aug19.pdf

Parker, M. D \& Ahijevych, D. A. (2007). Convective episodes in the east-central United States. Mon. Wea. Rev., 135, 3707-3727. https://doi.org/10.1175/2007MWR2098.1

Planchon, O., Damato F., Dubreuil V. \& Gouery P. (2006). A method of identifying and locating sea-breeze. fronts in north-eastern Brazil by remote sensing. Meteorol. Appl. 13, 225-234. https://doi.org/10.1017/ $\underline{\text { S1350482706002283 }}$

Ray, C. A. (1995). Detection of summertime convergence zones in central and eastern North Carolina using the WSR-88D Doppler Radar. M.S. thesis, Dept. of Marine, Earth and Atmospheric Sciences, North Carolina State University, 193 pp. [Available from University Microfilm, 305 N. Zeeb Rd., Ann Arbor, MI 48106.].

Savijärvi, H. \& Alestalo, M. (1988). The sea breeze over a lake or gulf as the function of the prevailing flow. Beitr. Phys. Atmos, 61(2), 98-104.

Shaw, W. J., Lundquist, J. K. \& Schreck, S. J. (2009). Research needs for wind resource characterization. Bull. Amer. Meteor. Soc., 90(4), 535-538. https://doi.org/10.1175/2008BAMS2729.1

Shepherd, J. M., Grundstein, A. \& Mote, T. (2007). Quantifying the contribution of tropical cyclones to extreme rainfall along the coastal southeastern United States. Geophys. Res. Letters, 34, L23810, https://doi.org/10.1029/2007GL031694

Simpson, J. E., Mansfield, D. \& Milford, J. (1977). Inland penetration of sea-breeze fronts. Q. J. Roy. Met. Soc., 103:435, 47-76. https://doi.org/10.1002/qj.49710343504

Sims, A. P., \& Raman, S. (2016). Interaction Between Two Distinct Mesoscale Circulations During Summer in the Coastal Region of Eastern USA, Boundary Layer Meteor., 160(1), 113-132. https://doi. org/10.1007/s10546-015-0125-6

State Climate Office of North Carolina (SCONCa). Retrieved 2017, from http://climate.ncsu.edu/climate/ monthlyprecip.html. 
State Climate Office of North Carolina (SCONCb). Retrieved 2017, from http://climate.ncsu.edu/climate/ ncclimate.html.

Steele, C. J., Dorling, S. R., von Glasow, R. \& Bacon, J. (2014). Modelling sea-breeze climatologies and interactions on coasts in the southern North Sea: implications for offshore wind energy. Q. J. Roy. Met. Soc., 141: 1821-1835. https://doi.org/10.1002/qj.2484

Wallace, J. M. \& Hobbs, P. V. (2006). Atmospheric science: An introductory survey. Amsterdam: Elsevier Academic Press.

Wilson, J. W., Weckwerth, T. M., Vivekanandan, J., Wakimoto, R. M. \& Russell, R. W. (1994). Boundary layer clear-air radar echoes: Origin of echoes and accuracy of derived winds. J. Atmospheric and Oceanic Technology, 11(5), 1184-1206. https://doi.org/10.1175/1520-0426(1994)011<1184:BLCARE $\geq 2.0 . \mathrm{CO} ; 2$

Winkler, J.A., Skeeter, B.R. \& Yamamoto, P.D. (1988). Seasonal variations in the diurnal characteristics of heavy hourly precipitation across the United States. Mon. Wea. Rev., 116(8), 1641-1658. https://doi. org/10.1175/1520-0493(1988)116<1641:SVITDC >2.0.CO;2

Wyoming Weather (2015). University of Wyoming, College of Engineering, Department of Atmospheric Science. Worldwide Radiosonde Soundings of the Atmosphere. Retrieved from http://weather.uwyo. edu/upperair/sounding.html

Zhong, S. \& Takle E. S. (1993). The effects of large-scale winds on the sea-land-breeze circulations in an area of complex coastal heating. J. Appl. Meteorol., 32, 1181-1195. https://doi.org/10.1175/15200450(1993)032<1181:TEOLSW>2.0.CO;2

Zhu, M. \& Atkinson, B. W. (2004). Observed and modeled climatology of the land-sea breeze circulation over the Persian Gulf. Int. J. Climatol., 24, 883-905. https://doi.org/10.1002/joc.1045 